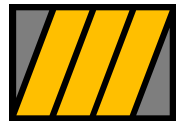

ESCUELA DE NEGOCIOS

Universidad Torcuato Di Tella

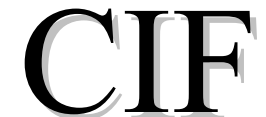

Centro de Investigación en Finanzas

Documento de Trabajo 01/2004

\title{
Market Discipline in Emerging Economies: Beyond Bank Fundamentals
}

Eduardo Levy Yeyati

(UTDT)

María Soledad Martínez Pería

(World Bank)

Sergio Schmukler

(World Bank)
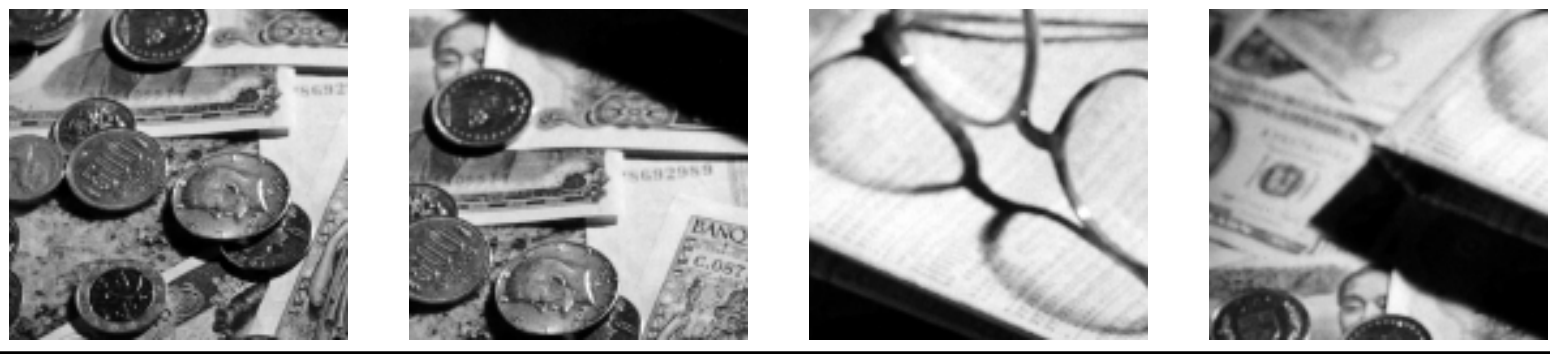

Miñones 2177, C1428ATG Buenos Aires • Tel: 4784.0080 interno 181 y 4787.9394 - Web site: www.utdt.edu/departamentos/empresarial/cif/cif.htm 


\title{
Market Discipline in Emerging Economies: Beyond Bank Fundamentals
}

\author{
Eduardo Levy-Yeyati $\quad$ Maria Soledad Martinez Peria $\quad$ Sergio L. Schmukler*
}

\begin{abstract}
This paper studies how institutional factors and systemic risks (driven by macroeconomic conditions) prevalent in emerging economies may impact market discipline among banks (traditionally understood as market responses to bank fundamentals). First, we discuss how certain institutional features of emerging economies (underdeveloped capital markets, pervasive government ownership of banks, greater guarantees, inadequate disclosure and transparency) may affect market responses to bank risk. Second, using the recent Argentine crisis as an illustration, we argue that systemic risks may exert an overwhelming impact on market behavior, overshadowing the link between the latter and bank fundamentals. Thus, market discipline, while missing in the traditional sense, may be indeed quite robust once systemic risks are factored in. We conclude that in emerging economies the analysis of market discipline should take into account the importance of institutional and systemic factors.
\end{abstract}

JEL classification codes: F30, F41, G14, G21, G28

Keywords: market discipline, emerging markets, banking crises

Forthcoming in

Market Discipline across Countries and Industries

Edited by William C. Hunter, George G. Kaufman, Claudio Borio, and Kostas Tsatsaronis

MIT Press

\footnotetext{
* Eduardo Levy-Yeyati is a professor at the Universidad Torcuato Di Tella. Maria Soledad Martinez Peria and Sergio Schmukler are both senior economists in the Development Research Group of The World Bank. Juan Miguel Crivelli, Federico Droller, and Marina Halac provided excellent research assistance. We are grateful to Francisco Gismondi, Claudio Irigoyen, Ricardo Martinez, and Luciana Rios-Benso for their help with the data on Argentina. For useful comments and suggestions we thank David Llewellyn, Roberto Rigobon, and participants at the conference "Market Discipline: The Evidence Across Countries and Industries," Federal Reserve Bank of Chicago, October 30 - November 1, 2003. The views expressed in this paper are entirely those of the authors and do not necessarily represent the views of the World Bank. E-mail addresses: ely@utdt.edu, mmartinezperia@worldbank.org, and sschmukler@worldbank.org, respectively.
} 


\section{Introduction}

The recent wave of financial crises has renewed the interest in market discipline in banking systems. This interest is not merely academic, but it is also apparent in recent policy initiatives such as the latest capital proposal by the Basel Committee on Banking Supervision. ${ }^{1}$ The New Basel Capital Accord put forward by this body has three main components or "pillars." Pillar 3 lays out a number of disclosure requirements that banks are recommended to comply with in order to enhance market discipline. As stated in BIS (2001), "market discipline has the potential to reinforce minimum capital standards (pillar 1) and the supervisory review process (pillar 2), and so promote safety and soundness in banks and financial systems."

Market discipline in banking is commonly understood as a situation in which private sector agents face costs that are positively related to the risks undertaken by banks and react on the basis of these costs (Berger, 1991). ${ }^{2}$ This reaction may materialize via prices (such as when depositors demand higher interest) or via quantities (for example, when depositors withdraw funds). Traditionally, the empirical literature has studied market discipline by testing market sensitivity to bank fundamentals, which, if present, has been interpreted as conducive to more prudent risk-taking practices and a healthier banking sector as a whole (hence, the emphasis on information disclosure as a prudential tool).

Both institutional and systemic factors may, however, have important effects on market discipline, at least as it has been traditionally defined. Institutional factors may affect market discipline indirectly, by influencing the degree to which agents react to changes in bank fundamentals. The existence of well-functioning markets, the degree of government ownership of banks, the presence of guarantees, and the level of disclosure and transparency may affect the incentives of and the information available to market participants to respond to banks' idiosyncratic risk.

Systemic risks (driven by macroeconomic factors) may affect market discipline both directly and indirectly. On the one hand, given bank fundamentals, worsening economic conditions can threaten the value of market participants' assets (such as the value of bank deposits) directly provoking adverse market responses. On the other hand, macroeconomic factors may induce a market reaction indirectly, by bringing about a deterioration of bank fundamentals, in particular for institutions heavily exposed to those risks. ${ }^{3}$ Given the influence of macroeconomic factors, the failure to find empirical evidence of market reaction to bank fundamentals does not imply the absence of market discipline. Rather, it reflects the fact that the informational content of observed fundamentals diminishes as market participants (such as depositors) react to expected changes in future fundamentals driven by large systemic shocks. Thus, for any given level of bank risk, bank fundamentals are likely to become less informative as the systemic component increases and market participants respond accordingly.

As noted, the empirical literature on market discipline has mostly focused on market reaction to bank fundamentals. ${ }^{4}$ However, this work has largely ignored how institutional and macroeconomic factors may affect their findings. ${ }^{5}$ Moreover, the view of market sensitivity as a disciplining device is indeed questionable when market reaction is driven by macroeconomic conditions largely beyond the control of bank managers. ${ }^{6}$ The impact of institutional and 
macroeconomic factors on market sensitivity and its implications for market discipline are the subjects of this paper.

\section{Institutional factors and market discipline}

In principle, various economic agents can exercise market discipline; bondholders, stockholders, credit rating agencies, and depositors are the usual candidates. Their ability to monitor and discipline financial firms depends crucially on the existence of deep, wellfunctioning markets where price and quantity movements convey useful information about the solvency of firms. When it comes to bond and stock markets, this point is not as trivial at it may sound. In the U.S., arguably the country with the most developed capital markets, only 15 percent of all banks issue equity, and a similar proportion of financial institutions have publicly traded debt outstanding (Flannery, 1998). In emerging economies, in part as a result of smaller firm size and relatively higher transaction costs, debt and equity issuance is likely to be even more rare (Figure 1a). Moreover, secondary markets tend to be very thin (Figure 1b). Therefore, price and quantity movements may become noisy signals of the underlying fundamentals, undermining their potential as a market discipline tool. This is clearly reflected in the fact that all existing studies of market discipline in emerging economies focus exclusively on the behavior of depositors. ${ }^{7}$

Government ownership of banks, more pervasive in emerging economies (Figure 1c), is another institutional factor that may influence market discipline for a number of reasons. ${ }^{8}$ First, government-owned banks are not publicly held, which already rules out stockholders as candidates for bank monitoring. Second, public banks are often perceived (usually correctly) as protected by implicit government guarantees, due not only to their size and systemic impact, but also to their role as vehicles for political lending. Finally, government ownership may contaminate market discipline in the private sector, both through the anticipation of a pari passu treatment of private institutions (which extends the guarantee and relaxes discipline across the board) and through contagion once a crisis is underway, as measures to protect public banks may have deleterious effects on the system as a whole.

Market discipline is also undermined by policies that credibly protect market agents from suffering losses. For example, "too big to fail" policies, which tend to be more prevalent in developing countries (Figure 1d), reduce the incentives of bank stakeholders to monitor risk. ${ }^{9}$ Deposit insurance schemes (DIS) are also likely to dampen market sensitivity. ${ }^{10}$ Furthermore, they tend to be more generous in emerging economies (Figure 1e). ${ }^{11}$ However, because they are frequently under-funded, their credibility is likely to be questioned, particularly at times of systemic crisis when fiscal solvency is also at stake. While, relative to developed countries, the net effect of a generous but undependable DIS is ex ante ambiguous, there is some indication that the credibility component tends to dominate. ${ }^{12}$

Last, but certainly not least, for market discipline to work, market participants must have access to the right information in a timely fashion. Emerging economies, while progressing rapidly, still tend to fare poorly on these fronts (Figure 1f). ${ }^{13}$ 
In sum, market discipline, as typically measured in the academic literature, may be difficult to find in a context in which some of the institutional constraints mentioned above are at play. But even if the institutional environment is conducive to an effective market monitoring, the relative importance of systemic risks in emerging economies may mask the link between market behavior and bank-specific fundamentals to the point of making it empirically unobservable. To this issue we turn next.

\section{Systemic risks and market discipline}

Institutional differences notwithstanding, perhaps the main distinctive factor influencing market discipline in emerging economies is the relative importance of systemic vis-à-vis idiosyncratic risks. The underlying sources of systemic risk are by now well known. On the one hand, relatively large real shocks combined with a strong dependence on highly pro-cyclical international capital flows (coupled with narrow domestic markets) yield large output volatility and a perilous propensity to fall into deep recessions. The latter can drastically deteriorate the repayment capacity of bank debtors and, in turn, bank solvency. On the other hand, the karma of weak domestic currencies often leads to the dollarization of domestic savings or, if this option is not allowed, to the shortening of deposits ready to fly away from banks to the foreign currency. The associated exchange rate and rollover risks tend to feed back on systemic financial fragility.

It is immediate to see how these systemic sources may overshadow the informational content of observed bank fundamentals. To the extent that banks are subject to large systemic risks that might threaten the value of their assets, depositors and investors will respond to fluctuations in those risks no matter how healthy bank fundamentals look or how well hedged banks appear ex-ante. Classic examples of systemic factors that can have a direct effect on market reactions include exchange rate risk and confiscation risk. Pure currency risk (as, for example, in the case of a "peso problem") could lead to deposit flight in those countries where onshore dollarization is restricted. ${ }^{14}$ A run may also be induced by the threat of confiscation by an insolvent government unable to rescue a few troubled "too-big-to-fail" institutions. ${ }^{15}$ Finally, systemic risks might overshadow the role of observed bank fundamentals due to their impact on expected changes in future fundamentals (e.g., through rapidly deteriorating non-performing ratios or, in the event of a currency run, through a liquidity crunch that can quickly become a solvency problem due to the collapse of the market value of bank assets).

In sum, the lack of evidence of market discipline as traditionally defined does not imply that market participants are not sensitive to risk or that bank withdrawals are random, as the existing, largely U.S.-based, literature would conclude. Rather it suggests that markets respond to a broader set of risks, which in the context of emerging economies are primarily driven by macroeconomic conditions.

The recent currency-cum-bank run in Argentina is a clear example of how markets, and in particular depositors, respond to systemic risks. ${ }^{16}$ In 1998, right before the beginning of the protracted recession that led to the crisis, Argentina was ranked among the most solid banking sectors within emerging countries based on standard fundamentals. ${ }^{17}$ Even by end-2000, Argentina could have been characterized as having a well-capitalized, highly liquid, strongly provisioned banking sector. Fundamentals, however, played a limited role in the run up to a 
crisis driven largely by systemic factors such exchange rate and default risk. It is not surprising, then, that banks were affected across the board, irrespective of their ownership structure and their financial condition.

This is clearly illustrated in Figure 2. The left hand side panels in Figure 2 shows the shift in the distribution of interest rates and changes in deposits across banks between the period December 2000-June 2001 and the period July 2001-December 2001. The figure shows that in the second half of 2001 interest rate hikes and deposit withdrawals affected all banks in the financial system. From the right hand side panels in Figure 2, it is clear that the interest rate and deposit movements that occurred in the second half of 2001 coincided with increases in currency risk, expressed in the non-deliverable forward (NDF) premium, and default or country risk, as measured by the Emerging Market Bond Index (EMBI) spread. Moreover, Figure 3 illustrates that deposit withdrawals and interest rate increases were more pronounced in banks with higher exposure to systemic risk (in this case measured by the exposure to exchange rate risk). Thus, these two figures suggest that depositors were indeed sensitive to how systemic risk would affect the value of their deposits, findings that are also confirmed by a more rigorous econometric analysis in Levy-Yeyati, Martinez Peria, and Schmukler (2003). ${ }^{18}$

Overall, these findings are not surprising. A long recession as a result of a deflationary real exchange rate adjustment pushed (private and public) dollarized debtors to the verge of bankruptcy, fueling expectations of a currency realignment and fostering further dollarization of bank deposits. In turn, anticipation of the devastating balance sheet effect of a nominal devaluation made it clear to depositors that the exit of the currency board would entail either massive bank insolvency or, given the perceived insolvency of the government, a debtor bailout in the form of a forceful conversion of dollar contracts at below market rates. These factors led to a run from the system.

Interestingly, for the sake of our argument, which of these two scenarios was in the mind of the fleeing depositor at any point in time is immaterial. Under the first scenario, observed fundamentals conveyed no relevant information about bank risk, as they would worsen sharply overnight. Under the second, the recovery value of deposits was fully dependent on the conversion rate picked by the government, irrespective of the health of individual banks. As a result, market discipline was then imposed on the market as a whole, following closely the evolution of the systemic indicators that were perceived as the best predictors of the impending currency collapse.

\section{Conclusions}

The quest for market discipline embedded in Basle's Pillar 3 and in recent proposals to get banks to issue subordinated debt moves in the right direction, by addressing the supervisor's limitations (both in terms of human capital and as a result of agency problems) to enforce compliance with prudential regulations. However, in the context of emerging markets, the discussion and analysis of market discipline should take into account two important factors that have been largely ignored so far. First, institutional constraints affecting incentives and information accuracy may narrow the scope for market discipline in emerging economies. Second, systemic risks may overshadow the role of bank fundamentals in driving market 
responses. Bank fundamentals, useful indicators of bank health in tranquil times, may fail to capture macroeconomic risk exposures that tend to materialize in the run-up to a crisis, and may be slow to incorporate the impact of macroeconomic risk once the latter becomes apparent. This is particularly so in crisis-prone emerging economies, where risk is of a systemic nature to a larger degree, as the recent Argentine episode illustrates.

In this light, we argue that the narrow definition of market discipline implicit in the empirical as well as the prudential literature needs to be revisited considerably for emerging economies. The incidence of systemic risk, while accounting for the weaker explanatory power of bank fundamentals in crisis periods, indicates that the information set to which market participants respond is wider than usually considered, and that market sensitivity to risk is quite robust when both idiosyncratic and systemic factors are taken into account. From a prudential perspective, our argument calls for a distinction between market responses to idiosyncratic factors, on one hand, and to systemic factors, on the other. Market responses to idiosyncratic risk can truly discipline bank managers, forcing them to run sound banks with healthy fundamentals. On the other hand, market responses to systemic risk may at times be independent of the behavior of bank fundamentals. In this environment, the only action managers can take to limit adverse market responses is to minimize (to the extent possible) their banks' exposure to systemic factors. 


\section{References}

Bank for International Settlements, 2001, "Working paper on pillar 3 - market discipline," Basel Committee on Banking Supervision, working paper, September.

Barajas, Adolfo, and Roberto Steiner, 2000, "Depositor behavior and market discipline in Colombia," International Monetary Fund Seminar Series, Vol. 51, September, pp. 1-39.

Barth, James R., Gerard Caprio Jr., and Ross Levine, 2001, "The regulation and supervision of banks around the world: a new database," in Robert E. Litan and Richard Herring (eds.), Brookings-Wharton papers on financial services, Washington: Brookings Institution Press.

Berger, Allen N., 1991, "Market Discipline in Banking," in Proceedings of a conference on bank structure and competition, Federal Reserve Bank of Chicago.

Budnevich, Carlos L., and Helmut M. Franken, 2003, "Disciplina de mercado en la conducta de los depositantes y rol de las agencias clasificadoras de riesgo: el caso de Chile," Economía Chilena, Vol. 6, August, pp. 45-70.

Calomiris, Charles. W., 1997, The postmodern bank safety net: lessons from developed and developing economies, Washington: American Enterprise Institute Press.

Calomiris, Charles W., 1999, "Building an incentive-compatible safety net," Journal of Banking and Finance, Vol. 23, October, pp. 1499-1519.

Calomiris, Charles W., and Andrew Powell, 2001, "Can emerging market bank regulators establish credible discipline? The case of Argentina, 1992-1999," in Frederic S. Mishkin (ed.), Prudential supervision, Chicago: University of Chicago Press.

Cordella, Tito, and Eduardo Levy-Yeyati, 1998, "Public disclosure and bank failures," IMF Staff Papers, Vol. 45, March, pp. 110-131.

De la Torre, Augusto, Eduardo Levy-Yeyati, and Sergio Schmukler, 2003, "Living and dying with hard pegs: the rise and fall of Argentina's currency board," Economia, Vol. 3, Spring, pp. 43-107.

Demirgüç-Kunt, Asli, and Harry Huizinga, 2003, "Market discipline and deposit insurance," Journal of Monetary Economics, forthcoming.

Demirgüç-Kunt, Asli, and Tolga Sobaci, 2001, "Deposit insurance around the world," World Bank Economic Review, Vol. 15, September, pp. 481-490.

Evanoff, Douglas D., and Larry D. Wall, 2000, "Subordinated debt as bank capital: a proposal for regulatory reform," Economic Perspectives, Vol. 25, May, pp. 40-53.

Flannery, Mark J., 1998, "Using market information in prudential bank supervision: a review of the U.S. empirical evidence," Journal of Money, Credit, and Banking, Vol. 30, August, pp. 273-305.

Ghosh, Saibal, and Abhiman Das, 2003, "Market discipline in the Indian banking sector: an empirical exploration," NSE Research Initiative, working paper.

Honohan, Patrick, and Daniela Klingebiel, 2003, "The fiscal cost implications of an accommodating approach to banking crises," Journal of Banking and Finance, Vol. 27, August, pp. 1539-1560.

Levy-Yeyati, Eduardo, Maria Soledad Martinez Peria, and Sergio Schmukler, 2003, "Market discipline and systemic risk in emerging economies," mimeo.

Martinez Peria, Maria Soledad, and Sergio Schmukler, 2001, "Do depositors punish banks for 'bad' behavior? Market discipline, deposit insurance, and banking crises," Journal of Finance, Vol. 56, June, pp. 1029-1051. 
Schumacher, Liliana, 2000, "Bank runs and currency run in a system without a safety net: Argentina and the 'Tequila' shock," Journal of Monetary Economics, Vol. 46, August, pp. 257-277.

Sironi, Andrea, 2003, "Testing for market discipline in the European banking industry: evidence from subordinated debt issues," Journal of Money, Credit and Banking, Vol. 35, June, pp. 443-472.

World Bank, 1998, “Argentina: financial sector review,” Report No. 17864-AR, September. 


\section{Endnotes}

${ }^{1}$ Other recent initiatives to enhance market discipline include proposals to make it mandatory for banks to issue subordinated debt. See Calomiris (1997, 1999) and Evanoff and Wall (2000).

${ }^{2}$ In the case of rating agencies, because they do not have a direct economic stake in the financial firms, the costs they suffer if they fail to rate banks according to their risk is primarily reputational.

${ }^{3}$ Take, for example, the impact of currency risk. If convertibility to a foreign currency is not an option, it may lead depositors to flee from the domestic banks irrespective of their individual health. Also, banks that are particularly sensitive to exchange rate risk might see their fundamentals deteriorate after a pronounced currency depreciation, and might suffer greater losses in deposits vis-à-vis less exposed banks.

${ }^{4}$ For a review of the U.S. literature on market discipline by stockholders, bondholders and depositors see Flannery (1998). Sironi (2003) offers evidence of discipline by subordinated debt holders in the European banking industry. Studies of depositor market discipline in developing countries are more limited, with this literature emerging only in the late 1990s. Some of these papers are Barajas and Steiner (2000) for Colombia, Bundevich and Franken (2003) for Chile, Ghosh and Das (2003) for India, and Schumacher (2000) for Argentina.

${ }^{5}$ Some exceptions are Martinez Peria and Schmukler (2001) and Demirgüç-Kunt and Huizinga (2003), who study the impact of deposit insurance.

${ }^{6}$ See Cordella and Levy-Yeyati (1998) for an analytical discussion of the link between information disclosure, market discipline, and the nature of the underlying risk.

${ }^{7}$ High costs of issuance and the presence of illiquid markets might also help explain why initiatives that promote regulations requiring banks in developing countries to issue subordinated debt as a vehicle for market discipline are likely to fail. In late 1996, in what is the only emerging market experiment to date, Argentina adopted a regulation according to which banks had to issue a subordinated liability for some two percent of their deposits each year. However, the plan was derailed by the increase in the domestic cost of capital that followed the Russian crisis, right after the regulation became effective in 1998. Repeatedly, the central bank was forced to relax the enforcement of the regulation by pushing forward the date for compliance, broadening the range of liabilities that banks could issue to meet the requirement, and reducing the penalties for non-compliance. Nonetheless, Calomiris and Powell (2001) find a positive correlation between those banks that issued subordinated debt and those that exhibited stronger fundamentals.

${ }^{8}$ Using data collected by Barth, Caprio, and Levine (2001), Figure 1c shows that the percentage of banking system assets in banks that are 50 percent or more government owned averages 23 percent among emerging economies, while the corresponding statistic is 11 percent for high income OECD countries and 8.5 percent for high income non-OECD countries.

${ }^{9}$ As the figure shows, out of the 40 crisis events reported in Honohan and Klingebiel (2003), recapitalizations with the use of fiscal funds occurred in 26 percent of the crises in emerging markets and in 11 percent in developed countries. Crony capitalism and regulatory capture can have comparable consequences, as depositors anticipate that even medium-sized institutions may be ultimately favored by regulatory forbearance of rescue packages if they fall in distress.

${ }^{10}$ Demirgüç-Kunt and Huizinga (2003), using a bank-level database comprising 30 (developed and developing) countries, find that explicit deposit insurance dampens the interest sensitivity to bank fundamentals.

${ }^{11}$ Using information gathered by Demirgüç-Kunt and Sobaci (2001), Figure 1e shows that coverage ratios (coverage limits over 1998 GDP per capita) average 2.4 among emerging markets and 1.8 among high income OECD countries.

${ }_{12}$ Martinez Peria and Schmukler (2001) find evidence of a comparable market response among insured and uninsured depositors in Argentina, Chile, and Mexico, which they attribute to the lack of confidence in the existing insurance schemes or implicit guarantees due to lack of funding or long delays in repayments.

${ }^{13}$ Barth, Caprio, and Levine (2001) construct an index of accounting disclosure and director liability based on (a) whether the income statement includes accrued or unpaid interest or principal on non-performing loans, (b) whether banks are required to produce consolidated financial statements, including non-bank financial affiliates or subsidiaries, and (c) whether bank directors are legally liable if the information disclosed is erroneous or misleading. The index ranges between 0 and 3 depending on whether countries comply with none, some, or all of the above.

${ }^{14}$ It is interesting to note that preventing these types of currency-induced runs was one of the reasons behind the lifting of restrictions on foreign currency deposits in many emerging economies.

${ }^{15}$ The placing of deposit rate caps and the ulterior suspension of deposit convertibility in Argentina in NovemberDecember 2001 may be explained, at least in part, using this argument. 
${ }^{16}$ For a detailed description and analysis of how the recent Argentine crisis unfolded, as well as the condition of the financial sector prior to the crisis, see De la Torre, Levy Yeyati, and Schmukler (2003).

${ }^{17}$ The World Bank (1998) ranked Argentina second among 12 emerging economies based on CAMELOT scores (the World Bank's version of the CAMEL rating).

${ }^{18}$ Using bank level panel estimations and VAR analysis with data for the system as a whole, the authors show that most of the evolution of deposit and interest rates during the crisis period is explained by macroeconomic indicators (such as currency and country risk), as well as indicators of bank exposure to those risks (such as the share of government debt and the ratio of dollar assets over bank capital). In particular, they find that peso and dollar deposits reacted negatively to increases both in individual banks' exposure to government default risk and in the country risk premium, while interest rates rose in response to these variables. The exchange rate risk premium, on the other hand, had a negative (positive) impact on peso deposits (interest rates) and a positive (negative) effect on dollar deposits (interest rates). 


\section{Figure 1 \\ Institutional Factors and Market Discipline}

1.a Stock Traded over GDP in 2001 (in percent)

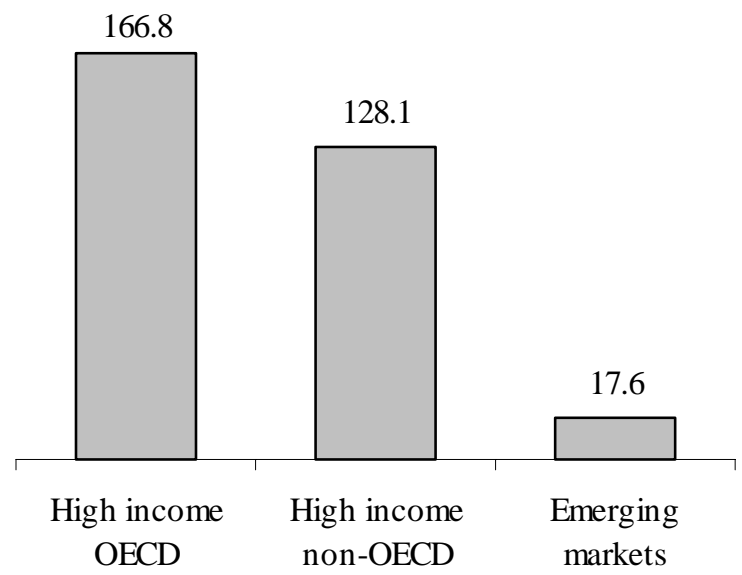

1.c Percentage of Assets in Banks that Are $50 \%$ or More Government Owned (1999)

23.2

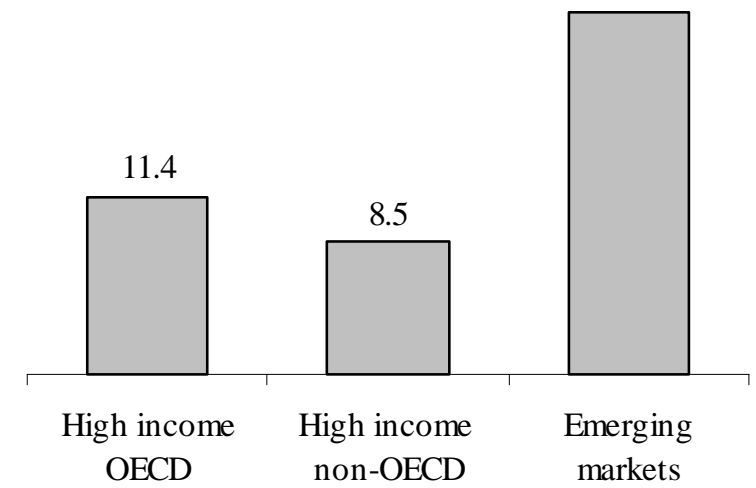

1.e Coverage Ratio: Coverage Limits over 1998 GDP Per Capita

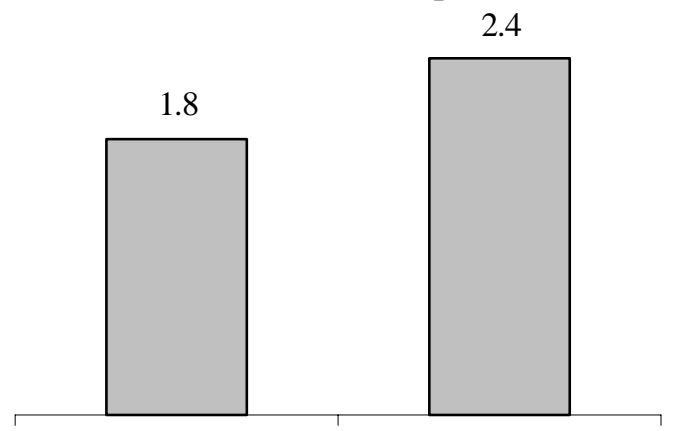

High income OECD Emerging markets 1.b Turnover Ratio in 2001 (in percent) 139.4

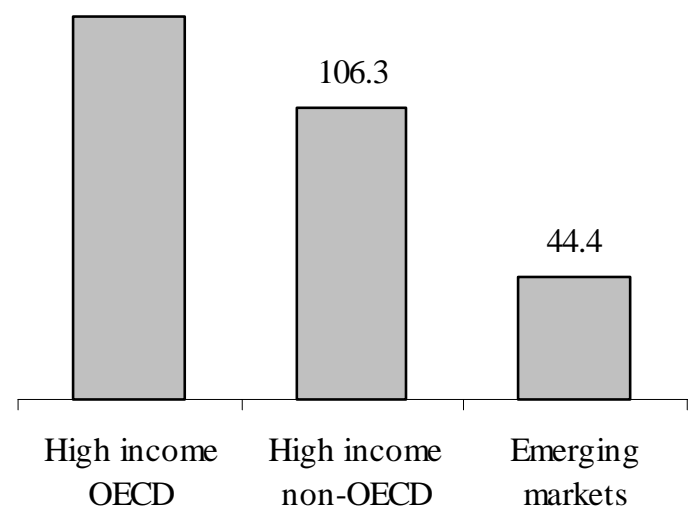

1.d Percentage of Crises where Banks Were Repeatedly Recapitalized

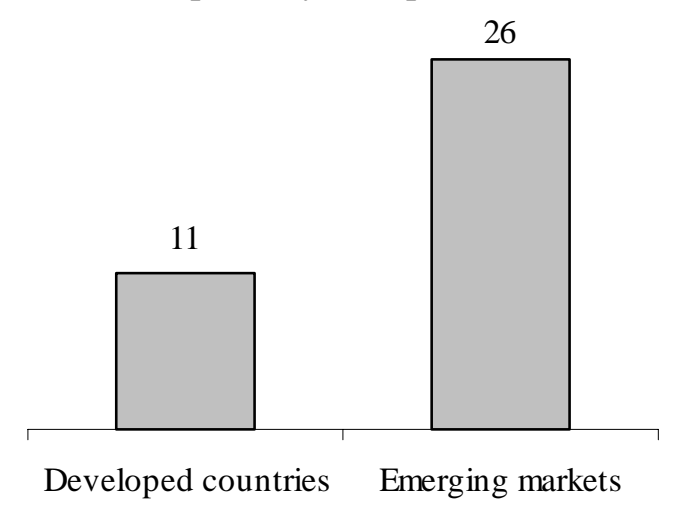

1.f Accounting Disclosure and Director Liability Index (1999)

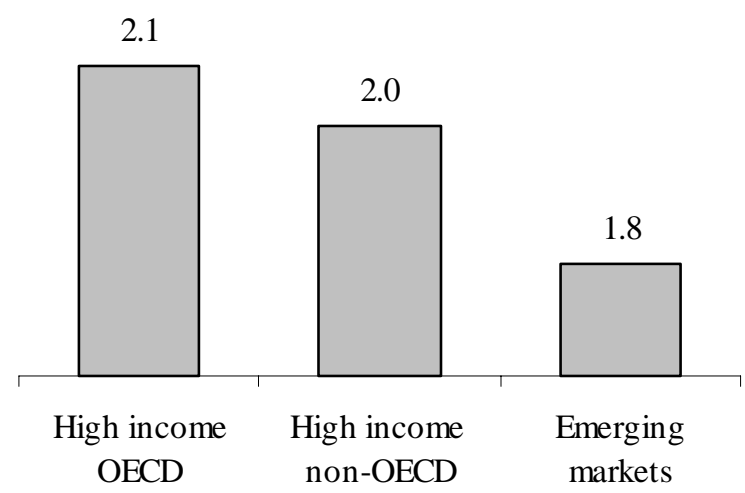

The figures show institutional features of developed and emerging economies. The composition of the country groups varies across figures due to limitations in the availability of data.

Sources: World Bank Development Indicators, Barth, Caprio, and Levine (2001), and Demirgüç-Kunt and Sobaci (2001) 
Figure 2

Deposits, Interest Rates, and Systemic Risk: Kernel Distributions

Change in Deposits and Interest Rates (in percent)
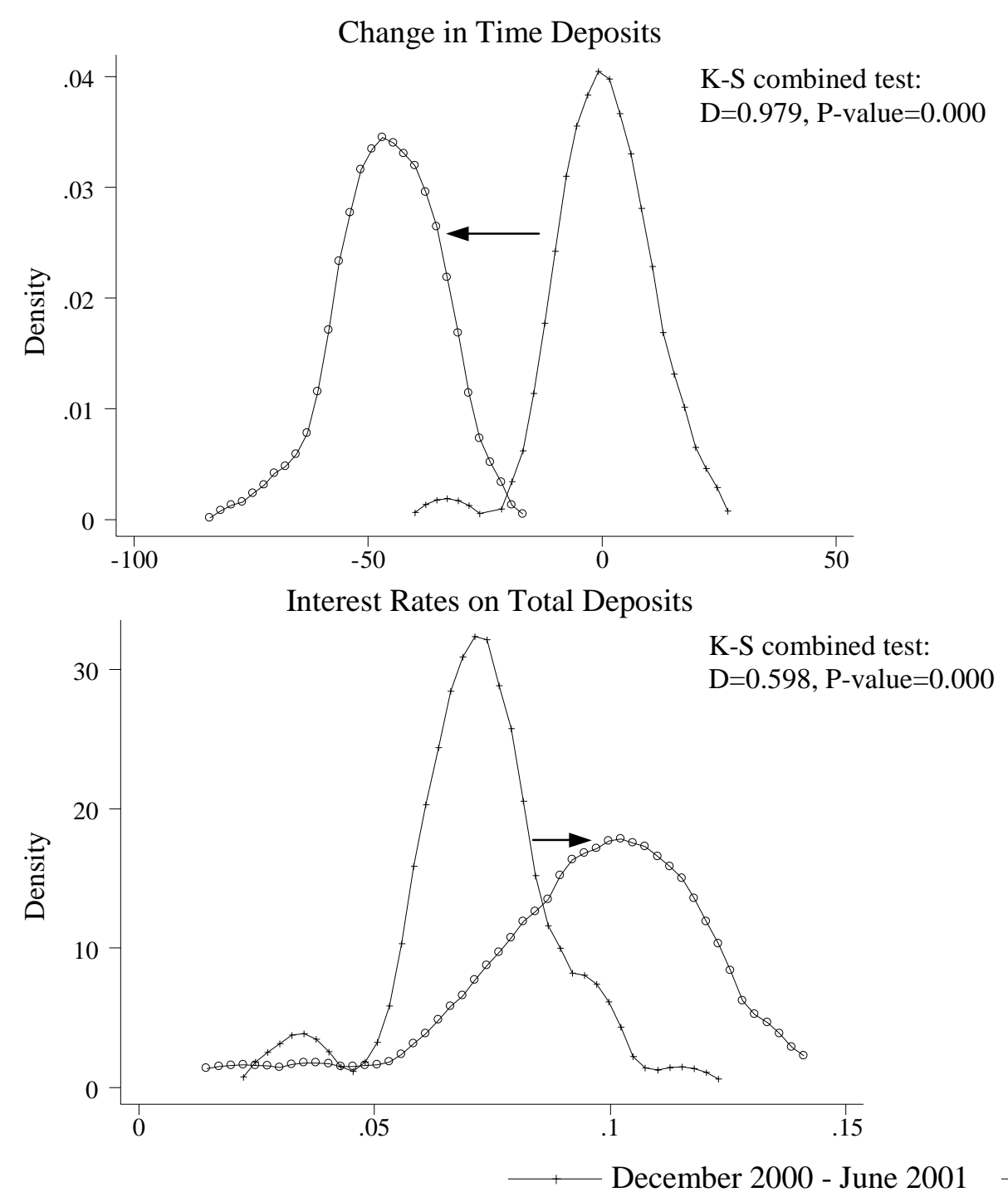

Systemic Risks (in percent)

EMBI Spread
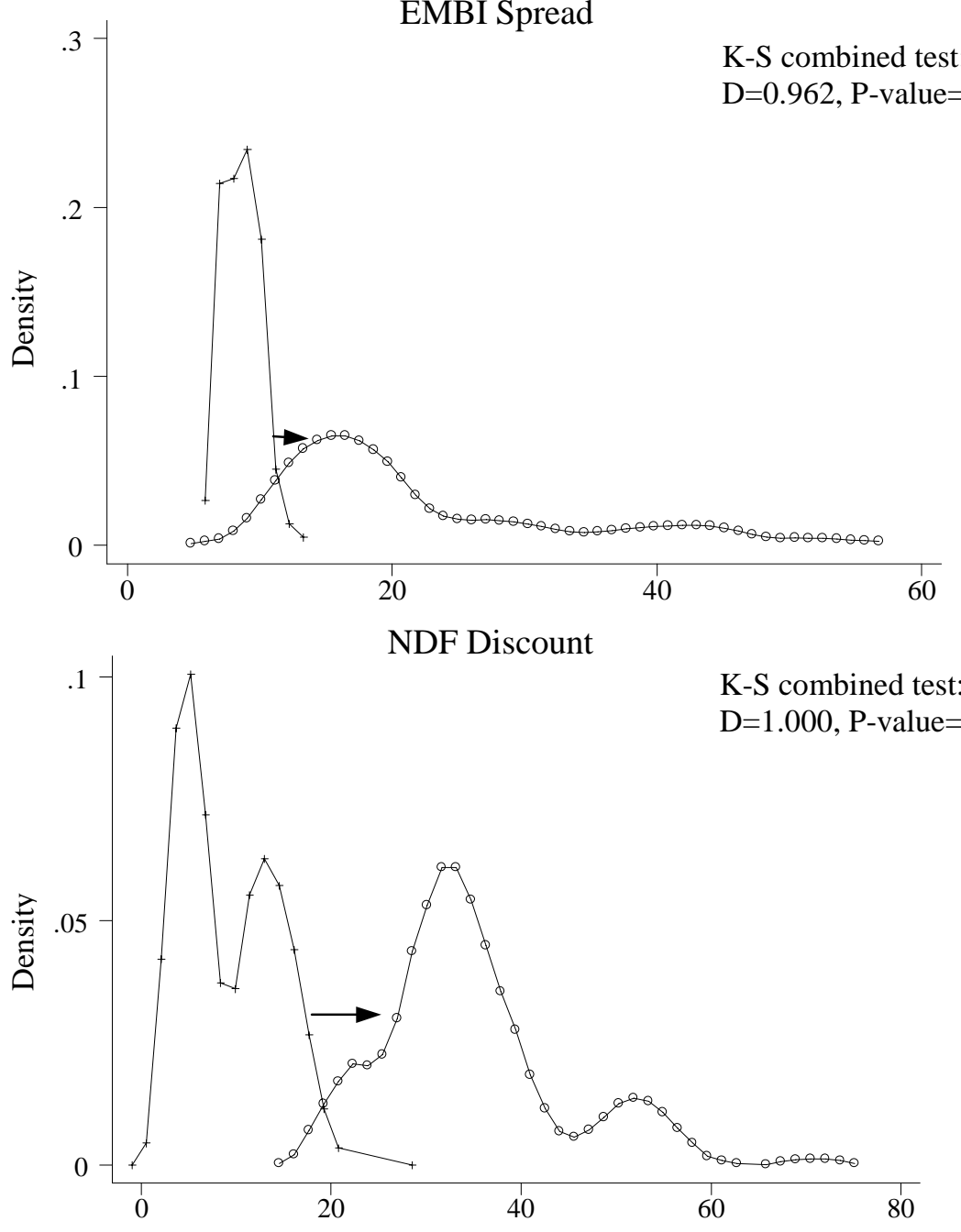

July 2001 - December 2001

The figures on the left show the Kernel distributions of the cumulative percent change in time deposits and the level of interest rates on total deposits across banks for the periods December 2000 - June 2001 and July 2001- December 2001. The figures on the right show the Kernel distributions of the daily EMBI spread and the daily NDF discount during the same periods. The two-sample Kolmogorov-Smirnov tests for equality of distribution functions indicate that the distributions are different across periods. Note that for several banks there is no data on interest rates for the period July 2001 - December 2001

Sources: Central Bank of Argentina, JP Morgan, and Bloomberg 
Figure 3

Change in Deposits and Interest Rates by Bank Exposure to Exchange Rate Risk

December 2000 - November 2001

Percent Change in Time Deposits

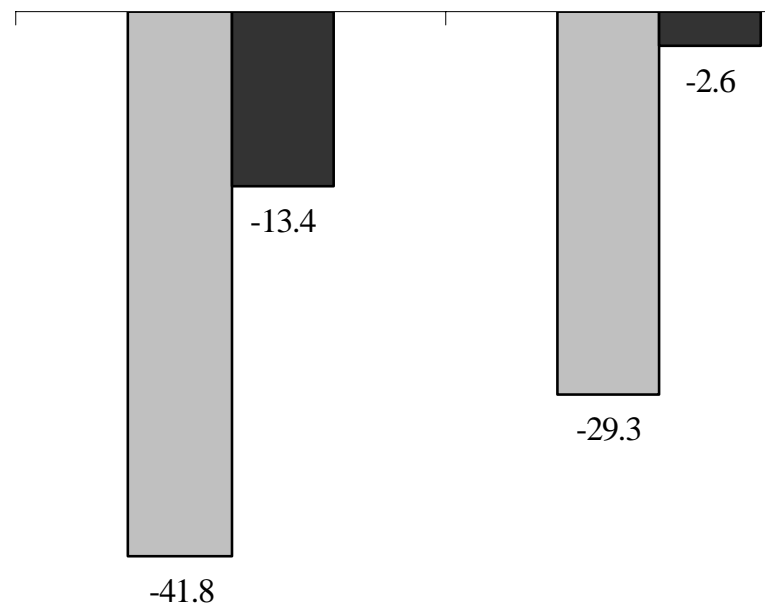

High exposure Low exposure

Change in Interest Rates on Time Deposits (percentage points)

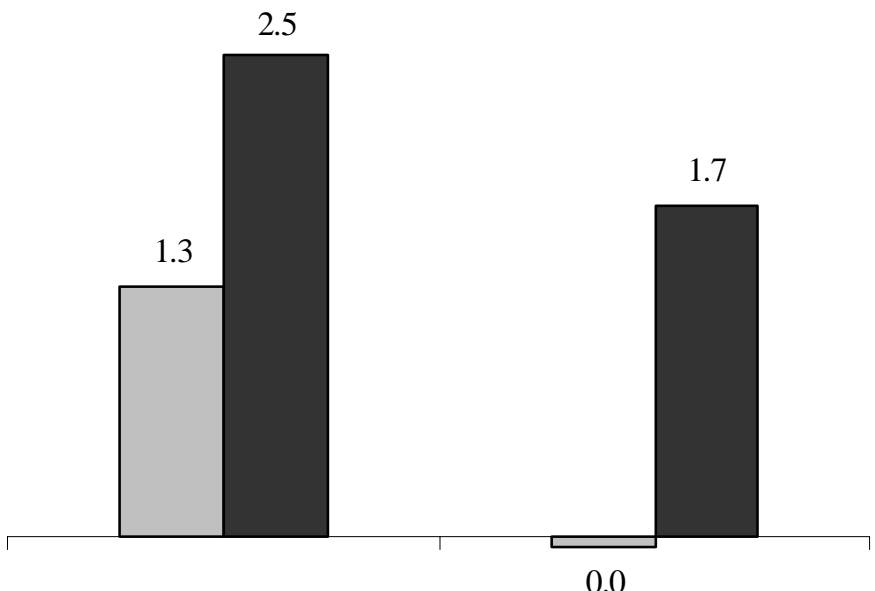

High exposure Low exposure

Peso deposits / interest rates

$\square$ Dollar deposits / interest rates

The figures show the percent change in time deposits and the change in interest rates (in percentage points) by currency during December 2000 - November 2001, differentiating banks with high and low exposure to exchange rate risk. Source: Central Bank of Argentina 


\section{Universidad Torcuato Di Tella, Business School Working Papers}

\section{Working Papers 2003}

NN16 "Business Cycle and Macroeconomic Policy Coordination in MERCOSUR"

Martín Gonzalez Rozada (UTDT) y José Fanelli (CEDES).

No15 "The Fiscal Spending Gap and the Procyclicality of Public Expenditure"

Eduardo Levy Yeyati (UTDT) y Sebastián Galiani (UDESA).

No14 "Financial Dollarization and Debt Deflation under a Currency Board"

Eduardo Levy Yeyati (UTDT), Ernesto Schargrodsky (UTDT) y Sebastián Galiani (UDESA).

№13 " ¿ Por qué crecen menos los regímenes de tipo de cambio fijo? El efecto de los Sudden Stops", Federico Stuzenegger (UTDT).

№12 "Concentration and Foreign Penetration in Latin American Banking Sectors: Impact on Competition and Risk", Eduardo Levy Yeyati (UTDT) y Alejandro Micco (IADB).

№11 "Default 's in the 1990's: What have we learned?",

Federico Sturzenegger (UTDT) y Punan Chuham (WB).

№10 "Un año de medición del Indice de Demanda Laboral: situación actual y perspectivas",

Victoria Lamdany (UTDT) y Luciana Monteverde (UTDT)

N'09 "Liquidity Protection versus Moral Hazard: The Role of the IMF",

Andrew Powell (UTDT) y Leandro Arozamena (UTDT)

№8 "Financial Dedollarization: A Carrot and Stick Approach", Eduardo Levy Yeyati (UTDT)

No07 "The Price of Inconvertible Deposits: The Stock Market Boom during the Argentine crisis",

Eduardo Levy Yeyati (UTDT), Sergio Schmukler (WB) y Neeltje van Horen (WB)

NN06 "Aftermaths of Current Account Crisis: Export Growth or Import Contraction?",

Federico Sturzenegger (UTDT), Pablo Guidotti (UTDT) y Agustín Villar (BIS)

No5 "Regional Integration and the Location of FDI",

Eduardo Levy Yeyati (UTDT), Christian Daude (UM ) y Ernesto Stein (BID)

N04 "A new test for the success of inflation targeting",

Andrew Powell (UTDT), Martin Gonzalez Rozada (UTDT) y Verónica Cohen Sabbán (BCRA)

No03 "Living and Dying with Hard Pegs: The Rise and Fall of Argentina's Currency Board",

Eduardo Levy Yeyati (UTDT), Augusto de la Torre (WB) y Sergio Schmukler (WB)

No02 "The Cyclical Nature of FDI flows",

Eduardo Levy Yeyati (UTDT), Ugo Panizza (BID) y Ernesto Stein (BID) 
№1 "Endogenous Deposit Dollarization",

Eduardo Levy Yeyati (UTDT) y Christian Broda (FRBNY)

\section{Working Papers 2002}

№15 "The FTAA and the Location of FDI",

Eduardo Levy Yeyati (UTDT), Christian Daude (UM ) y Ernesto Stein ( BID)

No14 "Macroeconomic Coordination and Monetary Unions in a N-country World: Do all Roads

Lead to Rome?"

Federico Sturzenegger (UTDT) y Andrew Powell (UTDT)

№13 "Reforming Capital Requirements in Emerging Countries"

Andrew Powell (UTDT), Verónica Balzarotti (BCRA) y Christian Castro (UPF)

№12 "Toolkit for the Analysis of Debt Problems", Federico Sturzenegger (UTDT)

№11 "On the Endogeneity of Exchange Rate Regimes",

Eduardo Levy Yeyati (UTDT), Federico Sturzenegger (UTDT) e lliana Reggio (UCLA)

№10 "Defaults in the 90's: Factbook and Preliminary Lessons", Federico Sturzenegger (UTDT)

No09 "Countries with international payments ' difficulties: what can the IMF do?"

Andrew Powell (UTDT)

NN08 "The Argentina Crisis: Bad Luck, Bad Management, Bad Politics, Bad Advice",

Andrew Powell (UTDT)

N07 "Capital Inflows and Capital Outflows: Measurement, Determinants, Consequences",

Andrew Powell (UTDT), Dilip Ratha (WB) y Sanket Mohapatra (CU)

No06 "Banking on Foreigners: The Behaviour of International Bank Lending to Latin America, 1985-2000",

Andrew Powell (UTDT), María Soledad Martinez Peria (WB) y Ivanna Vladkova ( IMF)

No05 "Classifying Exchange Rate Regimes: Deeds vs. Words"

Eduardo Levy Yeyati (UTDT) y Federico Sturzenegger (UTDT)

NN04 "The Effect of Product Market Competition on Capital Structure: Empirical Evidence from the

Newspaper Industry", Ernesto Schargrodsky (UTDT)

N03 "Financial globalization: Unequal blessings",

Augusto de la Torre (World Bank), Eduardo Levy Yeyati (Universidad Torcuato Di Tella) y Sergio

L. Schmukler (World Bank)

N02 "Inference and estimation in small sample dynamic panel data models",

Sebastian Galiani (UdeSA) y Martin Gonzalez-Rozada (UTDT)

№1 "Why have poverty and income inequality increased so much? Argentina 1991-2002",

Martín González-Rozada, (UTDT) y Alicia Menendez, (Princeton University). 